\title{
Antibiotic-potentiation activities of four Cameroonian dietary plants against multidrug-resistant Gram-negative bacteria expressing efflux pumps
}

Francesco K Touani, Armel J Seukep, Doriane E Djeussi, Aimé G Fankam, Jaurès A K Noumedem and Victor Kuete*

\begin{abstract}
Background: The continuous spread of multidrug-resistant (MDR) bacteria, partially due to efflux pumps drastically reduced the efficacy of the antibiotic armory, increasing the frequency of therapeutic failure. The search for new compounds to potentiate the efficacy of commonly used antibiotics is therefore important. The present study was designed to evaluate the ability of the methanol extracts of four Cameroonian dietary plants (Capsicum frutescens L. var. facilulatum, Brassica oleacera L. var. italica, Brassica oleacera L. var. butyris and Basilicum polystachyon (L.) Moench.) to improve the activity of commonly used antibiotics against MDR Gram-negative bacteria expressing active efflux pumps.
\end{abstract}

Methods: The qualitative phytochemical screening of the plant extracts was performed using standard methods whilst the antibacterial activity was performed by broth micro-dilution method.

Results: All the studied plant extracts revealed the presence of alkaloids, phenols, flavonoids, triterpenes and sterols. The minimal inhibitory concentrations (MIC) of the studied extracts ranged from 256-1024 $\mu \mathrm{g} / \mathrm{mL}$. Capsicum frutescens var. facilulatum extract displayed the largest spectrum of activity (73\%) against the tested bacterial strains whilst the lower MIC value $(256 \mu \mathrm{g} / \mathrm{mL})$ was recorded with Basilicum polystachyon against E. aerogenes ATCC 13048 and P. stuartii ATCC 29916. In the presence of PAßN, the spectrum of activity of Brassica oleacera var. italica extract against bacteria strains increased (75\%). The extracts from Brassica oleacera var. butyris, Brassica oleacera var. italica, Capsicum frutescens var. facilulatum and Basilicum polystachyon showed synergistic effects ( $F I C \leq 0.5)$ against the studied bacteria, with an average of $75.3 \%$ of the tested antibiotics.

Conclusion: These results provide promising information for the potential use of the tested plants alone or in combination with some commonly used antibiotics in the fight against MDR Gram-negative bacteria.

Keywords: Cameroonian dietary plants, Potentiation, Gram-negative bacteria, Multidrug resistant, Efflux pumps

\section{Background}

The spread of multidrug-resistant bacteria, partially due to the inappropriate use of common antibiotics, drastically reduced the efficacy of the antibiotic armory, increasing the frequency of therapeutic failure. The over-expression of efflux pumps is the main resistance mechanism observed in many bacteria [1]. In Gram-negative bacteria, many of these efflux pumps belong to the resistance-nodulation-cell

\footnotetext{
* Correspondence: kuetevictor@yahoo.fr

Department of Biochemistry, Faculty of Science, University of Dschang, P.O. Box 67, Dschang, Cameroon
}

division (RND), family of tripartite efflux pumps [2]. In the fight against microbial infections including those due to MDR bacteria, investigations are being carried out to discover new effective, none or less-toxic and available antibacterial drugs. Many scientist are also investigating synergistic compounds to potentiate the activity of the commonly used antibiotics [3]. The present work was designed to evaluate the in vitro ability of some edible plants namely Capsicum frutescens L. var. facilulatum (Solanaceae) or 'chili pepper', Brassica oleacera L. var. italica commonly known as 'Broccoli' and Brassica 
oleacera L. var. butyris (Brassicaceae) or 'Cauliflower'; and Basilicum polystachyon (L.) Moench. (Lamiaceae) or 'Musk Basil' to potentiate the effect of common antibiotics against Gram-negative MDR phenotypes.

\section{Methods}

\section{Plant material and extraction}

The plants used in this study were collected in Douala (Littoral Region of Cameroon) in January 2013. The plants were further identified at the National Herbarium (Yaoundé, Cameroon) where voucher specimens were deposited under a reference number (Table 1). Air dried and powdered sample $(0.1 \mathrm{~g})$ of each plant was extracted by maceration with methanol $(0.3 \mathrm{~L})$ for $48 \mathrm{~h}$ at room temperature $\left(25^{\circ} \mathrm{C}\right)$. After filtration using Whatman No. 1 filter paper, the filtrate of each plant was concentrated under reduced pressure in a rotary evaporator, and dried at room temperature to give the crude extract. The extraction yield was calculated (Table 2). These extracts were then stored at $4^{\circ} \mathrm{C}$ until further use.

\section{Preliminary phytochemical screenings}

The secondary metabolite classes such as alkaloids, anthocyanins, anthraquinones, flavonoids, phenols, saponins, tannins, sterols and triterpenes were screened according to the standard phytochemical methods described by Harbone [16].

\section{Bacteria strains and culture media}

The studied microorganisms included both reference (from the American Type Culture Collection, ATCC) and clinical (Laboratory collection) strains of Escherichia coli, Enterobacter aerogenes, Providencia stuartii, Pseudomonas aeruginosa and Klebsiella pneumoniae (Table 3). They were maintained at $4^{\circ} \mathrm{C}$ and sub-cultured on a fresh appropriate
Table 2 Extraction yields and phytochemical composition of the studied plants

\begin{tabular}{|c|c|c|c|c|}
\hline Extract & $\begin{array}{l}\text { Capsicum } \\
\text { frutescens }\end{array}$ & $\begin{array}{c}\text { Brassica } \\
\text { oleacera } \\
\text { var. butyris }\end{array}$ & $\begin{array}{c}\text { Brassica } \\
\text { oleacera } \\
\text { var. italica }\end{array}$ & $\begin{array}{c}\text { Basilicum } \\
\text { polystachyon }\end{array}$ \\
\hline Yield* (\%) & $7.22 \%$ & $12.18 \%$ & $7.31 \%$ & $8.61 \%$ \\
\hline Physical aspect & $\begin{array}{l}\text { Oily brown } \\
\text { and viscous }\end{array}$ & $\begin{array}{l}\text { Oily brown } \\
\text { and viscous }\end{array}$ & $\begin{array}{l}\text { Oily brown } \\
\text { and viscous }\end{array}$ & Compact \\
\hline Alkaloids & + & + & + & + \\
\hline Anthocyanins & - & - & - & - \\
\hline Anthraquinones & - & - & - & - \\
\hline Flavonoids & + & + & + & + \\
\hline Phenols & + & + & + & + \\
\hline Coumarins & - & - & - & + \\
\hline Tannins & - & + & + & - \\
\hline Triterpenes & + & + & + & + \\
\hline Sterols & + & + & + & + \\
\hline Saponins & - & + & - & + \\
\hline
\end{tabular}

$(+)$ : Present; (-): Absent; *yield calculated as the ratio of the mass of the obtained methanol extract/mass of the plant powder.

Mueller Hinton Agar (MHA) for 24 h before any antibacterial test. The Mueller Hinton Broth (MHB) was used for all antibacterial assays.

\section{Chemicals for antibacterial assays}

Nine commonly used antibiotics including tetracycline (TET), cefepime (CEP), streptomycin (STR), ciprofloxacin (CIP), norfloxacin (NOR), chloramphenicol (CHL), ampicillin (AMP), erythromycin (ERY), kanamycin (KAN) (Sigma-Aldrich, St Quentin Fallavier, France) were used for potentiation assay. $p$-Iodonitrotetrazolium chloride $0.2 \%$ (INT) and phenylalanine arginine $\beta$-naphthylamide

Table 1 Information on plants used in this study

\begin{tabular}{|c|c|c|c|c|}
\hline $\begin{array}{l}\text { Plants samples and herbarium } \\
\text { voucher number }\end{array}$ & Parts used & Popular names & Traditional used & Known antimicrobial activities of plants \\
\hline $\begin{array}{l}\text { Capsicum frutescens L. var. } \\
\text { facilulatum (Solanaceae) } \\
43079 / \text { HNC }\end{array}$ & Fruits & Green pepper & $\begin{array}{l}\text { Antimitogenic [4], } \\
\text { allergy, cancer and } \\
\text { viral infection [5] }\end{array}$ & $\begin{array}{l}\text { Antibacterial activities of aqueous and methanolic extracts } \\
\text { against Sa, St, Vc }[6,7] \text {, antifungal activities of lectin against } \\
\text { Af, [8]; antifungal activities of saponin CAY-1 against Ca, } \\
\text { Aspergillus Spp and dermatophytes Tm, Tr et Mc [9] }\end{array}$ \\
\hline $\begin{array}{l}\text { Brassica oleacera L. var. italica } \\
\text { (Brassicaceae) } 25686 / \text { SFR Cam }\end{array}$ & Leaves & Brocoli & $\begin{array}{l}\text { Oxydative stress, } \\
\text { cytotoxic [10] }\end{array}$ & $\begin{array}{l}\text { Antibacterial activities of ethanolic extractsagainst Sa, Bc, } \\
\mathrm{Pa}[11] . \text { Antifungal activities against Sc, Te, Hm, Pm [12]. }\end{array}$ \\
\hline $\begin{array}{l}\text { Brassica oleacera L. var. butyris } \\
\text { (Brassicaceae) } 25686 / \text { SFR Cam }\end{array}$ & Leaves & Flower cabbage & $\begin{array}{l}\text { Cytotoxic effect, } \\
\text { antiproliférative, } \\
\text { Oxydative stress [13]. }\end{array}$ & $\begin{array}{l}\text { Antibacterial activities of sulfur compounds MMTSO, AITC, } \\
\mathrm{MMTSO}_{2} \text { against Pp, Lm, Lp, Lb Lm Sa, Ea, Ec, Bs, St and } \\
\text { antifungal against strains Sc, Te, Hm, Pm [12]. }\end{array}$ \\
\hline $\begin{array}{l}\text { Basilicum polystachyon (L.) } \\
\text { Moench. (Lamiaceae) 38650/HNC }\end{array}$ & Leaves & $\begin{array}{l}\text { Cotimandjo } \\
\text { (Cameroon) }\end{array}$ & $\begin{array}{l}\text { Infectious diseases, } \\
\text { gastroenteritis [14]. }\end{array}$ & $\begin{array}{l}\text { Strong activities of acidic extracts against Gram (+), but } \\
\text { less activities against Gram;. Strong antifungal activities } \\
\text { of ethanolic and methanolic extracts against An [15]. }\end{array}$ \\
\hline
\end{tabular}

Af, Fm Ca, Tm, Tr, Tt, Mc, Sa, Bc, Ec, Pa, Sc, Te Hm, Pm, Pp, Lm, Lp, Lb, Lm, Bs, Ea, St, Te, Hm, An, Kp, Ec, Sm, Vc who are respectively : Aspergillus flavus, Fusarium moniliforme, Candidat albicans, trichophyton mentagrophytes, T. rubum, T.tonsuraus Microsporum canis, Staphylococcus aureus, Bacillus cereus, Escherichia coli, Pseudomonas aeroginosa, Saccharomyces cerevisiae, Torulopsis etchellsii, Hansenula mrakii, Pichia membranefaciens, Pediococcus pentosaceus, Leuconostoc mesenteroides, Lactobacillus plantarum , Lactobacillus brevis, Listeria monocytogenes, Bacillus subtilis, Enterobacter aerogenes, Salmonella. Typhimurium, Torulopsis etchellsii, Hansenula mrakii, Aspergillus niger, Klebsiella pneumoniae Cl, Enterobacter cloacae Cl, Clv Vibrio cholerae MMTSO: Méthylmethanethiosulfinate, AITC: Allyisothyocyanate, $\mathrm{MMTSO}_{2}$ : Méthylmethanethiosulfonat. SRFC: Company of Forest Reserve of Cameroon; HNC: Cameroon National Herbarium. 
Table 3 Bacterial strains and features

\begin{tabular}{|c|c|c|c|}
\hline Bacteria and strains & & Features & References \\
\hline \multirow[t]{6}{*}{ Escherichia coli } & ATCC 8739 & References strains & \\
\hline & ATCC 10536 & References strains & \\
\hline & AG100 Atet & AG 100 sur-expressing $A c r A B$ pumps, contaning $T^{2} T^{R}$ gène acrF & [14] \\
\hline & AG100 & Wild-typeE. ColiK-12 & [15] \\
\hline & AG102 & AG100 Sur-exprissing $A c r A B$ pumps. & {$[17]$} \\
\hline & MC4100 & Wild typeE. coli & \\
\hline \multirow[t]{7}{*}{ Enterobacter aerogenes } & ATCC 13048 & References strains & \\
\hline & EA27 & $\begin{array}{l}\text { Clinical MDR isolate exhibiting energy-dependent norfloxacin } \\
\text { and chloramphenicol efflux with } K^{-} N^{R} A M P^{R} N^{R} L^{R} S^{R} R^{R} T^{R}\end{array}$ & [18] \\
\hline & EA-3 & Clinical MDR isolate $\mathrm{CHL}^{\mathrm{R}}, \mathrm{NOR}^{R}, \mathrm{OFX}^{R}, \mathrm{SPX}^{R}, \mathrm{MOX}^{R}, \mathrm{CF}^{R}, \mathrm{ATM}^{R}, \mathrm{FEP}{ }^{R}$ & [18] \\
\hline & EA 289 & KAN sensitive derivative d'EA27 & [18] \\
\hline & EA 294 & EA289 sur-expressing AcrA pumps Exhibiting KAN ${ }^{R}$ & [18] \\
\hline & EA 298 & EA289 TolC KAN ${ }^{R}$ & [18] \\
\hline & CM64 & $\begin{array}{l}\mathrm{CHL}^{\mathrm{R}} \text { resistant variant obtained from ATCC13048 over-expressing } \\
\text { the AcrAB pump }\end{array}$ & {$[18]$} \\
\hline \multirow[t]{5}{*}{ Klebsiella pneumoniae } & ATCC 11296 & References strains & \\
\hline & $\mathrm{K}-2$ & $\begin{array}{l}\text { Clinical MDR isolate exhibiting energy-dependent norfloxacin } \\
\text { and chloramphenicol efflux with KAN }{ }^{R} M^{R} P^{R} N^{R}{ }^{R} T_{R}^{R} T^{R} T^{R}\end{array}$ & $\begin{array}{l}\text { Laboratory collection of UNR-MD1, } \\
\text { University of Marseille, France }\end{array}$ \\
\hline & $K-24$ & AcrAB-Tolc & \\
\hline & KP 55 & Clinical isolate MDR, TET ${ }^{R}, \mathrm{AMP}^{R}, \mathrm{ATM}^{R}, \mathrm{CEF}^{R}$ & {$[17]$} \\
\hline & KP 63 & Clinical isolate du MDR, $\mathrm{TET}^{\mathrm{R}}, \mathrm{CHL}^{\mathrm{R}} \mathrm{AMP}^{\mathrm{R}}, \mathrm{ATM}^{\mathrm{R}}$ & {$[17]$} \\
\hline \multirow[t]{2}{*}{ Pseudomonas aeruginosa } & PA01 & References strains & \\
\hline & PA124 & MDR Clinical isolate & [15] \\
\hline \multirow[t]{2}{*}{ Providencia stuartii } & ATCC 29916 & References strains & \\
\hline & NAE16 & MDR clinical isolate AcrAB-TolC & [15] \\
\hline
\end{tabular}

${ }^{\mathrm{a}} \mathrm{AMP}, \mathrm{ATM}^{\mathrm{R}}, \mathrm{CEF}^{\mathrm{R}}, \mathrm{CFT}^{\mathrm{R}}, \mathrm{CHL}^{\mathrm{R}}, \mathrm{FEP}^{\mathrm{R}}, \mathrm{KAN}^{\mathrm{R}}, \mathrm{MOX}^{\mathrm{R}}, \mathrm{STR}^{\mathrm{R}}, \mathrm{TET}^{\mathrm{R}}$. Resistance to ampicillin, aztreonam, cephalothin, cefadroxil, chloramphenicol, cefepime, kanamycin, moxalactam, streptomycin, and tetracycline; OMPF and OMPC: Outer Membran Protein F and C respectively. AcrAB-Tol: Efflux pump of type AcrAB associated to one porine of type TolC.

$(\mathrm{PA} \beta \mathrm{N})$ (Sigma-Aldrich) were used as bacterial growth indicator and efflux pumps inhibitor respectively. Dimethylsulfoxide 10\% (DMSO) was used as solvent for all extracts.

\section{Bacterial susceptibility determinations}

The minimal inhibitory concentrations (MIC) of the plant extracts against the studied bacteria were determined by rapid INT colorimetric assay $[19,20]$. Briefly, the test samples were first dissolved in DMSO/MHB. The solution obtained was then added to MHB in a 96-well microplate followed by a two fold serial dilution. One hundred microliters $(100 \mu \mathrm{L})$ of inoculum $\left(1.5 \times 10^{6} \mathrm{CFU} / \mathrm{mL}\right)$ prepared in $\mathrm{MHB}$ was then added. The plates were covered with a sterile plate sealer, then agitated to mix the contents of the wells using a shaker and incubated at $37^{\circ} \mathrm{C}$ for $18 \mathrm{~h}$. The final concentration ranges were $8-1024 \mu \mathrm{g} / \mathrm{mL}$ for plant extracts and 2-512 $\mu \mathrm{g} / \mathrm{mL}$ for reference antibiotic chloramphenicol (CHL). Wells containing MHB $(100 \mu \mathrm{L}), 100 \mu \mathrm{L}$ of inoculum and DMSO at a final concentration of $2.5 \%$ served as negative growth inhibition control. MIC was detected after $18 \mathrm{~h}$ of incubation at $37^{\circ} \mathrm{C}$, following addition
$(40 \mu \mathrm{L})$ of $0.2 \mathrm{mg} / \mathrm{mL}$ INT and incubation at $37^{\circ} \mathrm{C}$ for $30 \mathrm{~min}$. Viable bacteria reduced the yellow dye to pink. MIC was defined as the lowest sample concentration that prevented this change and exhibited complete inhibition of bacterial growth [21]. The minimal bactericidal concentrations $(\mathrm{MBC})$ of the samples was determined by taking $50 \mu \mathrm{L}$ of the suspensions from the wells which did not show any growth after incubation during MIC assays to a new 96-well microplate containing $150 \mu \mathrm{L}$ of fresh broth per well. The plate was further re-incubated at $37^{\circ} \mathrm{C}$ for 48 hours the addition of INT. The MBC was defined as the lowest concentration of samples which completely inhibited the growth of bacteria. Samples were tested alone and in the presence of $P A \beta N$ at $30 \mu \mathrm{g} / \mathrm{mL}$ final concentration [22].

To evaluate the potentiating effect of tested extracts, a preliminary combination at their sub-inhibitory concentrations (MIC/2, MIC/5, MIC/10 and MIC/20) with antibiotics was assessed against $P$. aeruginosa PA124 strain. The appropriate sub-inhibitory concentrations were then selected on the basis of their ability to improve the activity 
of the maximum antibiotic. These sub-inhibitory concentrations for selected extracts were further tested in combination with antibiotics against more MDR bacteria. The Fractional inhibitory concentration (FIC) of each combination was then calculated as the ratio of MIC of Antibiotic in combination versus MIC of Antibiotic alone [23,24].

\section{Results}

Phytochemical composition of the tested plant's extracts The results of the qualitative phytochemical analysis showed that each of the studied extract contained alkaloids, phenols, flavonoids, triterpenes and sterols. None of them contained anthocyanins and anthraquinones. Other phytochemical classes have been selectively detected as shown in Table 2.

\section{Antibacterial activity of the plant's extracts}

Bacterial strains and MDR isolates were tested for their susceptibility to plant extracts and chloramphenicol. The results summarized in Table 4 the selectivity of the extracts towards the tested bacteria, with MIC values ranging from 256 to $1024 \mu \mathrm{g} / \mathrm{mL}$ on the majority of the 22 tested microorganisms. Capsicum frutescens extract displayed the largest spectrum of activity, 73\% (16/22) against the tested bacteria; followed by Brassica oleacera var. italica, 50\% (11/22); Basilicum polystachyon 41\% (9/22) and Brassica oleacera var. butyris 27\% (6/22) extracts. The lowest MIC value $(256 \mu \mathrm{g} / \mathrm{mL})$ was recorded with Basilicum polystachyon extract against P. stuartii (ATCC 29916) and E. aerogenes (ATCC 13048). No significant $\mathrm{MBC}$ value was recorded.

Eight (8) of the twenty two (22) studied MDR bacteria were also tested for their susceptibility to the plant extracts in the presence of PA $\beta \mathrm{N}$ (Table 5). The largest spectrum of activity was recorded with $B$. oleacera var. butyris extract against 75\% (6/8) tested MDR bacteria. This efflux pumps inhibitor (EPI) also improved the activity of $C$. frutescens extract against E. coli (AG100), K. pneumoniae (KP53) and $E$. aerogenes (EA27) as well as that of $B$. polystachyon against $P$. stuartii (NAE16).

\section{Antibacterial activity of extract-antibiotic combination}

A preliminary assay against $P$. aeruginosa PA124 strain allowed selecting $\mathrm{MIC} / 2$ and $\mathrm{MIC} / 5$ as appropriate subinhibitory concentrations to be used on other bacteria

Table 4 MIC and MBC of the tested plants extracts and CHL on the studied bacterial species

\begin{tabular}{|c|c|c|c|c|c|c|c|c|c|c|c|}
\hline \multirow[t]{2}{*}{ Strains bacterial } & & \multicolumn{2}{|c|}{$\begin{array}{l}\text { Capsicum } \\
\text { frutescens }\end{array}$} & \multicolumn{2}{|c|}{$\begin{array}{c}\text { Brassica oleacera } \\
\text { var. varbutyris }\end{array}$} & \multicolumn{2}{|c|}{$\begin{array}{c}\text { Brassica oleacera } \\
\text { var. italica }\end{array}$} & \multicolumn{2}{|c|}{$\begin{array}{c}\text { Basilicum } \\
\text { polystachyon }\end{array}$} & \multicolumn{2}{|c|}{ Chloramphenicol } \\
\hline & & $\overline{M I C}$ & $\overline{M B C}$ & MIC & MBC & MIC & MBC & MIC & MBC & MIC & MBC \\
\hline \multirow[t]{6}{*}{ Escherichia coli } & ATCC 8739 & - & - & 1024 & - & - & - & - & - & 8 & 512 \\
\hline & ATCC 10536 & 512 & - & - & - & 1024 & - & - & - & 2 & 128 \\
\hline & AG100 Atet & 512 & - & 1024 & - & 1024 & - & 512 & 1024 & 64 & 64 \\
\hline & AG100 & - & - & - & - & - & - & - & - & 16 & 128 \\
\hline & AG102 & 1024 & - & - & - & 1024 & - & 1024 & - & 8 & - \\
\hline & MC4100 & 1024 & - & 512 & - & 512 & - & 1024 & - & 128 & 128 \\
\hline \multirow[t]{7}{*}{ Enterobacter aerogenes } & ATCC 13048 & 1024 & - & 1024 & - & 1024 & - & 256 & - & 8 & 32 \\
\hline & EA27 & - & - & - & - & - & - & - & - & 256 & NT \\
\hline & $\mathrm{EA}-3$ & 1024 & - & - & - & 1024 & - & 1024 & - & - & - \\
\hline & EA294 & - & - & - & - & - & - & - & - & 256 & 512 \\
\hline & EA298 & 512 & - & - & - & - & - & - & - & 4 & 16 \\
\hline & EA 289 & 1024 & - & - & - & - & - & - & - & 128 & - \\
\hline & CM64 & 1024 & - & - & - & 1024 & - & - & - & 128 & - \\
\hline \multirow[t]{5}{*}{ Klebsiella pneumoniae } & ATCC 11296 & 1024 & - & 1024 & - & 1024 & - & - & - & 8 & 512 \\
\hline & $\mathrm{K}-2$ & 512 & - & - & - & 1024 & - & 512 & - & 64 & NT \\
\hline & $K-24$ & 1024 & - & - & - & 1024 & - & 1024 & - & 16 & 256 \\
\hline & KP 55 & 1024 & - & - & - & - & - & 512 & - & 32 & - \\
\hline & KP 63 & 512 & - & - & - & - & - & - & - & 128 & NT \\
\hline \multirow[t]{2}{*}{ Pseudomonas aeruginosa } & PA01 & - & - & - & - & - & - & - & - & 64 & NT \\
\hline & PA124 & - & - & - & - & - & - & - & - & 512 & NT \\
\hline \multirow[t]{2}{*}{ Providencia stuartii } & ATCC 29916 & 1024 & - & 1024 & - & 1024 & - & 256 & - & 4 & 32 \\
\hline & NAE16 & 1024 & - & - & - & - & - & - & - & 256 & NT \\
\hline
\end{tabular}


Table 5 Antibacterial activities of extracts alone and in the presence of PABN

\begin{tabular}{ccccccc}
\hline Bacterial strains & Capsicum frutescens & Brassica oleacera var. butyris & Brassica oleacera var. italica & Basilicum polystachyon & CHL & PAßN \\
\hline AG100 & $1024(256)$ & $-(1024)$ & $-(1024)$ & $-(-)$ & $16(4)$ & $>128$ \\
AG100 Atet & $512(512)$ & $1024(512)$ & $1024(1024)$ & $-(-)$ & $64(32)$ & $>128$ \\
CM64 & $1024(1024)$ & $-(-)$ & $1024(512)$ & $1024(1024)$ & $128(64)$ & $>128$ \\
EA27 & $-(512)$ & $-(128)$ & $-(512)$ & $-(-)$ & $256(64)$ & $>128$ \\
KP55 & $-(-)$ & $-(1024)$ & $-(1024)$ & $-(-)$ & $64(8)$ & $>128$ \\
KP63 & $512(256)$ & $-(1024)$ & $-(-)$ & $-(-)$ & $128(16)$ & $>128$ \\
PA124 & $-(-)$ & $-(-)$ & $-(-)$ & $-(-)$ & $512(128)$ & $>128$ \\
NAE16 & $-(-)$ & $-(1024)$ & $-(-)$ & $-(1024)$ & $256(64)$ & $>128$ \\
\hline
\end{tabular}

( ): MIC value of extract in presence of PAßN; -: $>1024 \mu \mathrm{g} / \mathrm{mL}$ for extracts and $>512 \mu \mathrm{g} / \mathrm{mL}$ for antibiotic; $\mathrm{CHL}$ : Chloramphenicol.

(Table 6). Synergistic effects were observed with all the tested extracts. Brassica oleacera var. italica and B. oleacera var. butyris extracts potentiate $(0.125<\mathrm{FIC}<0.5$ and $0.031<$ FIC $<0.5$ respectively) the effects of the majority of antibiotics on most of the tested MDR bacteria (Table 7). Extracts from $C$. frutescens and $B$. polystachyon showed synergistic effects with six of the nine studied antibiotics, with $0.125<\mathrm{FIC}<0.5$ and $0.25<\mathrm{FIC}<0.5$ respectively.

\section{Discussion}

The Pharmacological potencies of plants' secondary metabolites are well demonstrated. The qualitative phytochemical screening of the plant extracts showed the presence of several classes of secondary metabolites, such as alkaloids, flavonoids, phenols, triterpenes, sterols, saponins, tannins and coumarins. Several antibacterial activities associated to the presence of compounds belonging to these various classes were shown [25-27]. It should however be mentioned that the detection of an alleged bioactive class of secondary metabolite in a plant is not a guarantee for any biological property, as this will depend on the nature of the compounds as well as their concentrations and the possible interactions with other constituents [12]. The differences observed between the antibacterial activities of the extracts as observed in the present work could be due to the differences in their phytochemical composition [9]. According to the criteria of classification of the antibacterial activity of the phytochemicals [28], the extracts used in this study were moderately and/or weak active $(256 \leq \mathrm{MIC}<1024 \mu \mathrm{g} / \mathrm{mL})$. Their direct

Table 6 MICs of antibiotics in combination with plant extracts against $P$. aeruginosa PA124

\begin{tabular}{|c|c|c|c|c|c|c|c|c|c|c|}
\hline Plants' extracts & & CEF & AMP & CIP & ERY & KAN & TET & STR & $\mathrm{CHL}$ & NOR \\
\hline ATB & ALONE & $-(-)$ & $-(-)$ & 64 & 512 & 128 & 64 & 64 & 512 & 256 \\
\hline \multirow[t]{4}{*}{ Capsicum frutescens } & $\mathrm{MIC} / 2$ & $-(-)$ & $-(-)$ & $32(0,5)^{\mathrm{s}}$ & $256(0,5)^{\mathrm{S}}$ & $128(1)^{1}$ & $32(0,5)^{5}$ & $256(4)^{1}$ & $256(0,5)^{\mathrm{S}}$ & $128(0,5)^{\mathrm{s}}$ \\
\hline & $\mathrm{MIC} / 5$ & $-(-)$ & $-(-)$ & $32(0,5)^{S}$ & $256(0,5)^{S}$ & $128(1)^{1}$ & $64(1)^{1}$ & $256(4)^{1}$ & $256(0,5)^{\mathrm{S}}$ & $128(0,5)^{\mathrm{S}}$ \\
\hline & $\mathrm{MIC} / 10$ & $-(-)$ & $-(-)$ & $32(0,5)^{\mathrm{s}}$ & $256(0,5)^{S}$ & $128(1)^{1}$ & $64(1)^{1}$ & $256(4)^{1}$ & $256(0,5)^{\mathrm{S}}$ & $128(0,5)^{\mathrm{S}}$ \\
\hline & $\mathrm{MIC} / 20$ & $-(-)$ & $-(-)$ & $64(1)^{1}$ & $256(0,5)^{S}$ & $256(2)^{1}$ & $64(1)^{1}$ & $256(4)^{1}$ & $256(0,5)^{S}$ & $128(0,5)^{\mathrm{s}}$ \\
\hline \multirow[t]{4}{*}{ Brassica oleacera var. butyris } & $\mathrm{MIC} / 2$ & $-(-)$ & $-(-)$ & $32(0,5)^{\mathrm{s}}$ & $256(0,5)^{\mathrm{S}}$ & $16(0,125)^{\mathrm{s}}$ & $16(0,25)^{\mathrm{S}}$ & $32(0,5)^{\mathrm{S}}$ & $256(0,5)^{\mathrm{S}}$ & $128(0,5)^{s}$ \\
\hline & $\mathrm{MIC} / 5$ & $-(-)$ & $-(-)$ & $32(0,5)^{S}$ & $256(0,5)^{S}$ & $16(0,125)^{\mathrm{S}}$ & $16(0,25)^{S}$ & $32(0,5)^{S}$ & $256(0,5)^{S}$ & $128(0,5)^{\mathrm{S}}$ \\
\hline & $\mathrm{MIC} / 10$ & $-(-)$ & $-(-)$ & $32(0,5)^{\mathrm{S}}$ & $256(0,5)^{\mathrm{S}}$ & $16(0,125)^{\mathrm{s}}$ & $32(0,25)^{\mathrm{S}}$ & $32(0,5)^{\mathrm{S}}$ & $256(0,5)^{\mathrm{S}}$ & $128(0,5)^{\mathrm{s}}$ \\
\hline & $\mathrm{MIC} / 20$ & $-(-)$ & $-(-)$ & $32(0,5)^{\mathrm{S}}$ & $256(0,5)^{S}$ & $32(0,25)^{\mathrm{S}}$ & $32(0,25)^{\mathrm{S}}$ & $64(1)^{1}$ & $256(0,5)^{\mathrm{S}}$ & $128(0,5)^{\mathrm{s}}$ \\
\hline \multirow[t]{4}{*}{ Brassica oleacera var. Italica } & $\mathrm{MIC} / 2$ & $-(-)$ & $-(-)$ & $32(0,5)^{\mathrm{s}}$ & $256(0,5)^{\mathrm{S}}$ & $128(1)^{1}$ & $32(0,25)^{\mathrm{s}}$ & $32(0,5)^{\mathrm{S}}$ & $256(0,5)^{\mathrm{S}}$ & $128(0,5)^{s}$ \\
\hline & $\mathrm{MIC} / 5$ & $-(-)$ & $-(-)$ & $64(1)^{1}$ & $256(0,5)^{\mathrm{S}}$ & $128(1)^{1}$ & $32(0,25)^{\mathrm{S}}$ & $32(0,5)^{\mathrm{S}}$ & $256(0,5)^{\mathrm{S}}$ & $128(0,5)^{s}$ \\
\hline & $\mathrm{MIC} / 10$ & $-(-)$ & $-(-)$ & $64(1)^{1}$ & $256(0,5)^{S}$ & $128(1)^{1}$ & $32(0,25)^{\mathrm{S}}$ & $64(1)^{1}$ & $512(1)^{1}$ & $256(1)^{1}$ \\
\hline & $\mathrm{MIC} / 20$ & $-(-)$ & $-(-)$ & $64(1)^{1}$ & $256(0,5)^{\mathrm{S}}$ & $128(1)^{1}$ & $64(1)^{1}$ & $64(1)^{1}$ & $512(1)^{1}$ & $256(1)^{1}$ \\
\hline \multirow[t]{4}{*}{ Basilicum polystachyon } & $\mathrm{MIC} / 2$ & $-(-)$ & $-(-)$ & $32(0,5)^{\mathrm{S}}$ & $128(0,25)^{\mathrm{S}}$ & $256(2)^{1}$ & $64(1)^{1}$ & $64(1)^{1}$ & $256(0,5)^{S}$ & $256(1)^{1}$ \\
\hline & $\mathrm{MIC} / 5$ & $-(-)$ & $-(-)$ & $32(0,5)^{5}$ & $256(0,5)^{\mathrm{S}}$ & $256(2)^{1}$ & $64(1)^{1}$ & $64(1)^{1}$ & $256(0,5)^{\mathrm{S}}$ & $256(1)^{1}$ \\
\hline & $\mathrm{MIC} / 10$ & $-(-)$ & $-(-)$ & $64(1)^{1}$ & $256(0,5)^{\mathrm{S}}$ & $256(2)^{1}$ & $64(1)^{1}$ & $64(1)^{1}$ & $256(0,5)^{\mathrm{S}}$ & $256(1)^{1}$ \\
\hline & $\mathrm{MIC} / 20$ & $-(-)$ & $-(-)$ & $64(1)^{1}$ & $256(0,5)^{\mathrm{S}}$ & $256(2)^{1}$ & $64(1)^{1}$ & $64(1)^{1}$ & $256(0,5)^{\mathrm{S}}$ & $256(1)^{1}$ \\
\hline
\end{tabular}

s: Synergy; 1: Indifference; A: Antagonism; ( ): fractional inhibitory concentration or FIC; -: MIC > 512 $\mu \mathrm{g} / \mathrm{mL}$; ATB: Antibiotic; CIP: Ciprofloxacin, NOR: Norfloxacin, CHL: Chloramphenicol, STR: Streptomycin, TET: Tetracycline, KAN: Kanamycin, ERY: Erythromycin, AMP: Ampicillin and CEF: Cefepime; The values in bold represent the cases of synergy between extract and antibiotic. 
Table 7 MIC of antibiotics in combination with plant at their MIC/2 and MIC/5 against selected MDR bacteria strains

\begin{tabular}{|c|c|c|c|c|c|c|c|c|c|c|}
\hline \multirow[t]{3}{*}{ Antibiotics } & \multicolumn{10}{|c|}{ Plant extracts and MIC } \\
\hline & \multirow[t]{2}{*}{$\begin{array}{l}\text { Bacterial } \\
\text { strains }\end{array}$} & \multirow[b]{2}{*}{ MIC } & \multicolumn{2}{|c|}{$\begin{array}{l}\text { Capsicum } \\
\text { frutescens }\end{array}$} & \multicolumn{2}{|c|}{$\begin{array}{l}\text { Brassica oleacera } \\
\text { var. butyris }\end{array}$} & \multicolumn{2}{|c|}{$\begin{array}{c}\text { Brassica oleacera } \\
\text { var. Italica }\end{array}$} & \multicolumn{2}{|c|}{$\begin{array}{c}\text { Basilicum } \\
\text { polystachyon }\end{array}$} \\
\hline & & & $\mathrm{MIC} / 2$ & $\mathrm{MIC} / 5$ & $\mathrm{MIC} / 2$ & $\mathrm{MIC} / 5$ & $\mathrm{MIC} / 2$ & $\mathrm{MIC} / 5$ & $\mathrm{MIC} / 2$ & $\mathrm{MIC} / 5$ \\
\hline \multirow[t]{7}{*}{ CEF } & AG100 & - & - & - & - & - & - & - & - & - \\
\hline & EA27 & 256 & - & - & - & - & $128(0.5)^{s}$ & $256(1)^{1}$ & $256(1)^{1}$ & $256(1)^{1}$ \\
\hline & CM64 & - & - & - & - & - & - & - & - & - \\
\hline & KP55 & - & - & - & - & - & - & - & - & - \\
\hline & KP63 & - & - & - & - & - & - & - & - & - \\
\hline & NAE16 & - & - & - & - & - & - & - & - & - \\
\hline & PA124 & & & & & & & & & \\
\hline \multirow[t]{6}{*}{ AMP } & AG100 & - & - & - & - & - & - & - & - & - \\
\hline & EA27 & - & - & - & - & - & - & - & - & - \\
\hline & CM64 & - & - & - & - & - & - & - & - & - \\
\hline & KP55 & - & - & - & - & - & - & - & - & - \\
\hline & KP63 & - & - & - & - & - & - & - & - & - \\
\hline & NAE16 & - & - & - & - & - & - & - & - & - \\
\hline \multirow[t]{7}{*}{ CIP } & AG100 & 32 & $32(1)^{\prime}$ & $64(2)^{1}$ & $8(0.25)^{5}$ & $8(0.25)^{5}$ & $64(2)^{1}$ & $64(2)^{\prime}$ & $64(2)^{1}$ & $128(4)^{1}$ \\
\hline & EA27 & 16 & $32(2)^{1}$ & $32(2)^{1}$ & $4(0.25)^{\mathrm{S}}$ & $4(0.25)^{5}$ & $8(0.5)^{5}$ & $8(0.5)^{5}$ & $128(8)^{A}$ & $128(8)^{\mathrm{A}}$ \\
\hline & CM64 & 16 & $16(1)^{\prime}$ & $16(1)^{\prime}$ & $16(1)^{\prime}$ & $16(1)^{\prime}$ & $16(1)^{\prime}$ & $16(1)^{\prime}$ & $64(4)^{1}$ & $128(8)^{\mathrm{A}}$ \\
\hline & KP55 & 16 & $4(0.25)^{S}$ & $8(0.5)^{S}$ & $2(0.125)^{S}$ & $4(0.25)^{5}$ & $4(0.25)^{S}$ & $16(1)^{1}$ & $8(0.5)^{5}$ & $8(0.5)^{S}$ \\
\hline & KP63 & $8^{*}$ & $4(0.5)^{S}$ & $4(0.5)^{5}$ & $1 *(0.125)^{S}$ & $1^{*}(0.125)^{S}$ & $1(0.125)^{S}$ & $4(0.25)^{S}$ & $16(1)^{\prime}$ & $16(1)^{\prime}$ \\
\hline & NAE16 & $8^{*}$ & $2(0.25)^{S}$ & $2(0.25)^{5}$ & $2^{*}(0.25)^{\mathrm{S}}$ & $2^{*}(0.25)^{\mathrm{S}}$ & $2(0.25)^{5}$ & $2(0.25)^{S}$ & $8^{*}(1)^{1}$ & $8(1)^{\prime}$ \\
\hline & PA124 & 64 & $32(0.5)^{S}$ & $32(0.5)^{S}$ & $32(0.5)^{S}$ & $32(0.5)^{S}$ & $32(0.5)^{S}$ & $64(1)^{1}$ & $32(0.5)^{S}$ & $32(0.5)^{S}$ \\
\hline \multirow[t]{7}{*}{ ERY } & AG100 & 32 & $16(0.5)^{5}$ & $16(0.5)^{5}$ & $8(0.25)^{5}$ & $8(0.25)^{5}$ & $16(0.5)^{S}$ & $16(0.5)^{s}$ & $64(2)^{1}$ & $64(2)^{1}$ \\
\hline & EA27 & 32 & $32(1)^{\prime}$ & $32(1)^{\prime}$ & $64(2)^{1}$ & $64(2)^{1}$ & $64(2)^{1}$ & $64(2)^{1}$ & $64(2)^{1}$ & $64(2)^{1}$ \\
\hline & CM64 & 32 & $64(2)^{1}$ & $16(0.5)^{\mathrm{S}}$ & $32(1)^{\prime}$ & $32(1)^{\prime}$ & $32(1)^{1}$ & $32(1)^{1}$ & $64(2)^{1}$ & $64(2)^{1}$ \\
\hline & KP55 & 128 & $128(1)^{1}$ & $128(1)^{\prime}$ & $64(0.5)^{\mathrm{S}}$ & $64(0.5)^{\mathrm{S}}$ & $64(0.5)^{S}$ & $128(1)^{\prime}$ & $256(2)^{1}$ & $256(2)^{1}$ \\
\hline & KP63 & 128 & $32(0.25)^{\mathrm{S}}$ & $64(0.5)^{5}$ & $32(0.25)^{\mathrm{S}}$ & $64(0.5)^{5}$ & $64(0.5)^{5}$ & $64(0.5)^{5}$ & $256(2)^{1}$ & $256(2)^{1}$ \\
\hline & NAE16 & 128 & $16(0.125)^{S}$ & $16(0.125)^{S}$ & $32(0.25)^{\mathrm{S}}$ & $64(0.5)^{5}$ & $128(1)^{\prime}$ & $128(1)^{\prime}$ & $256(2)^{1}$ & $256(2)^{1}$ \\
\hline & PA124 & 512 & $256(0.5)^{S}$ & $256(0.5)^{S}$ & $2560.5)^{S}$ & $256(0.5)^{S}$ & $256(0.5)^{S}$ & $256(0.5)^{S}$ & $128(0.25)^{S}$ & $2560.5)^{S}$ \\
\hline \multirow[t]{7}{*}{ KAN } & AG100 & 32 & $32(1)^{\prime}$ & $64(2)^{1}$ & $16(0.5)^{S}$ & $16(0.5)^{\mathrm{S}}$ & $32(1)^{1}$ & $32(1)^{\prime}$ & $32(1)^{\prime}$ & $32(1)^{\prime}$ \\
\hline & EA27 & 32 & $8(0.25)^{5}$ & $8(0.25)^{5}$ & $8(0.25)^{5}$ & $8(0.25)^{5}$ & $16(0.5)^{s}$ & $16(0.25)^{S}$ & $64(2)^{1}$ & $64(2)^{1}$ \\
\hline & CM64 & 64 & $64(1)^{\prime}$ & $64(1)^{\prime}$ & $16(0.25)^{\mathrm{S}}$ & $32(0.5)^{\mathrm{S}}$ & $32(0.5)^{5}$ & $32(0.5)^{\mathrm{S}}$ & $32(0.5)^{\mathrm{S}}$ & $32(0.5)^{S}$ \\
\hline & KP55 & 64 & $16(0.25)^{\mathrm{S}}$ & $16(0.25)^{\mathrm{S}}$ & $16(0.25)^{\mathrm{S}}$ & $16(0.25)^{\mathrm{S}}$ & $16(0.25)^{5}$ & $16(0.25)^{\mathrm{S}}$ & $16(0.25)^{\mathrm{S}}$ & $16(0.25)^{\mathrm{s}}$ \\
\hline & KP63 & 64 & $64(1)^{\prime}$ & $64(1)^{\prime}$ & $16(0.25)^{\mathrm{S}}$ & $16(0.25)^{\mathrm{S}}$ & $16(0.25)^{S}$ & $32(0.5)^{\mathrm{S}}$ & $32(0.5)^{\mathrm{S}}$ & $32(0.5)^{S}$ \\
\hline & NAE16 & 64 & $64(1)^{\prime}$ & $64(1)^{\prime}$ & $32(0.5)^{S}$ & $32(0.5)^{S}$ & $64(1)^{\prime}$ & $64(1)^{\prime}$ & $64(1)^{\prime}$ & $64(1)^{\prime}$ \\
\hline & PA124 & 128 & $128(1)^{1}$ & $128(1)^{1}$ & $16(0.125)^{S}$ & $16(0.125)^{S}$ & $128(1)^{\prime}$ & $128(1)^{1}$ & $256(2)^{1}$ & $256(2)^{1}$ \\
\hline \multirow[t]{7}{*}{ TET } & AG100 & 32 & $8(0.25)^{S}$ & $8(0.25)^{S}$ & $16(0.5)^{S}$ & $16(0.5)^{S}$ & $4(0.25)^{S}$ & $4(0.125)^{S}$ & $16(0.5)^{\mathrm{S}}$ & $32(1)^{\prime}$ \\
\hline & EA27 & 128 & $64(0.5)^{5}$ & $64(0.5)^{5}$ & $16(0.125)^{s}$ & $16(0.125)^{s}$ & $4(0.031)^{5}$ & $32(0.25)^{\mathrm{S}}$ & $64(0.5)^{5}$ & $64(0.5)^{5}$ \\
\hline & CM64 & 64 & $128(2)^{1}$ & $128(2)^{1}$ & $4(0.062)^{S}$ & $8(0.125)^{S}$ & $64(1)^{\prime}$ & $64(1)^{\prime}$ & $128(2)^{1}$ & $256(4)^{1}$ \\
\hline & KP55 & 16 & $2(0.125)^{S}$ & $4(0.25)^{S}$ & $1(0.062)^{S}$ & $1(0.062)^{S}$ & $2(0.125)^{S}$ & $2(0.125)^{S}$ & $16(1)^{\prime}$ & $16(1)^{\prime}$ \\
\hline & KP63 & 32 & $8(0.25)^{S}$ & $8(0.25)^{5}$ & $8(0.25)^{S}$ & $16(0.5)^{\mathrm{S}}$ & $16(0.5)^{\mathrm{S}}$ & $8(0.25)^{S}$ & $16(0.5)^{\mathrm{S}}$ & $16(0.5)^{S}$ \\
\hline & NAE16 & 128 & $64(0.5)^{S}$ & $64(0.5)^{5}$ & $128(1)^{\prime}$ & $128(1)^{\prime}$ & $64(0.5)^{S}$ & $64(0.5)^{S}$ & - & - \\
\hline & PA124 & 64 & $32(0.5)^{\mathrm{S}}$ & $64(1)^{\prime}$ & $16(0.25)^{\mathrm{S}}$ & $16(0.25)^{\mathrm{S}}$ & $32(0.5)^{S}$ & $32(0.5)^{S}$ & $64(1)^{1}$ & $64(1)^{\prime}$ \\
\hline STR & AG100 & 64 & $256(4)^{1}$ & $256(4)^{1}$ & $128(1)^{\prime}$ & $128(1)^{\prime}$ & $64(0.5)^{S}$ & $128(1)^{\prime}$ & $128(1)^{1}$ & $128(1)^{\prime}$ \\
\hline
\end{tabular}


Table 7 MIC of antibiotics in combination with plant at their MIC/2 and MIC/5 against selected MDR bacteria strains (Continued)

\begin{tabular}{|c|c|c|c|c|c|c|c|c|c|c|}
\hline & EA27 & 8 & $32(4)^{1}$ & $32(4)^{1}$ & $4(0.5)^{\mathrm{S}}$ & $8(1)^{\prime}$ & $2(0.25)^{5}$ & $2(0.5)^{S}$ & $8(1)^{\prime}$ & $8(1)^{1}$ \\
\hline & CM64 & 64 & $256(4)^{1}$ & $256(4)^{1}$ & $8(0.125)^{5}$ & $16(0.5)^{S}$ & $16(0.5)^{\mathrm{S}}$ & $16(0.5)^{S}$ & $64(1)^{1}$ & $64(1)^{\prime}$ \\
\hline & KP55 & 16 & $32(4)^{1}$ & $32(4)^{1}$ & $16(1)^{\prime}$ & $16(1)^{\prime}$ & $16(1)^{\prime}$ & $16(1)^{\prime}$ & $16(1)^{\prime}$ & $16(1)^{\prime}$ \\
\hline & KP63 & 64 & $256(4)^{1}$ & $256(4)^{1}$ & $128(1)^{1}$ & $128(1)^{1}$ & $128(1)^{1}$ & $128(1)^{1}$ & $128(1)^{1}$ & $128(1)^{1}$ \\
\hline & NAE16 & 64 & $256(4)^{1}$ & $256(4)^{1}$ & $64(0.5)^{5}$ & $64(0.5)^{5}$ & $64(0.5)^{5}$ & $64(0.5)^{S}$ & $128(1)^{\prime}$ & $128(1)^{\prime}$ \\
\hline & PA124 & 64 & $256(4)^{1}$ & $256(4)^{1}$ & $32(0.5)^{\mathrm{S}}$ & $32(0.5)^{S}$ & $32(0.5)^{S}$ & $32(0.5)^{\mathrm{S}}$ & $64(1)^{1}$ & $64(1)^{1}$ \\
\hline \multirow[t]{7}{*}{$\mathrm{CHL}$} & AG100 & 16 & $4(0.25)^{S}$ & $4(0.25)^{S}$ & $4(0.25)^{S}$ & $4(0.25)^{S}$ & $16(1)^{\prime}$ & $16(1)^{\prime}$ & $16(1)^{\prime}$ & $16(1)^{\prime}$ \\
\hline & EA27 & 256 & - & - & $64(0.25)^{\mathrm{S}}$ & $128(0.5)^{\mathrm{S}}$ & $32(0.125)^{S}$ & $64(0.25)^{\mathrm{S}}$ & $256(1)^{\prime}$ & $256(1)^{\prime}$ \\
\hline & CM64 & 128 & $32(0.25)^{\mathrm{S}}$ & $32(0.25)^{\mathrm{S}}$ & $16(0.125)^{\mathrm{S}}$ & $16(0.125)^{\mathrm{S}}$ & $64(0.5)^{\mathrm{s}}$ & $64(0.5)^{5}$ & $256(2)^{1}$ & $256(2)^{1}$ \\
\hline & KP55 & 64 & $32(0.5)^{\mathrm{S}}$ & $32(0.5)^{\mathrm{S}}$ & $16(0.25)^{\mathrm{S}}$ & $32(0.5)^{\mathrm{S}}$ & $32(0.5)^{S}$ & $32(0.5)^{S}$ & $64(1)^{1}$ & $64(1)^{1}$ \\
\hline & KP63 & 128 & $128(1)^{\prime}$ & $128(1)^{\prime}$ & $64(0.5)^{s}$ & $64(0.5)^{5}$ & $32(0.125)^{S}$ & $32(0.5)^{\mathrm{S}}$ & $64(0.5)^{\mathrm{S}}$ & $64(0.5)^{S}$ \\
\hline & NAE16 & 256 & $16(0.062)^{\mathrm{S}}$ & $32(0.125)^{S}$ & $8(0.031)^{5}$ & $16(0.062)^{S}$ & $32(0.125)^{\mathrm{S}}$ & $32(0.125)^{S}$ & $128(0.5)^{\mathrm{S}}$ & $128(0.5)^{S}$ \\
\hline & PA124 & 512 & $256(0.5)^{S}$ & $256(0.5)^{S}$ & $256(0.5)^{S}$ & $256(0.5)^{S}$ & $256(0.5)^{\mathrm{S}}$ & $256(0.5)^{\mathrm{S}}$ & $256(0.5)^{\mathrm{S}}$ & $256(0.5)^{S}$ \\
\hline \multirow[t]{7}{*}{ NOR } & AG100 & 16 & $16(1)^{\prime}$ & $16(1)^{\prime}$ & $4(0.25)^{\mathrm{S}}$ & $8(0.5)^{S}$ & $8(0.5)^{S}$ & $8(0.5)^{S}$ & $16(1)^{\prime}$ & $16(1)^{\prime}$ \\
\hline & EA27 & 16 & $128(4)^{1}$ & $128(4)^{1}$ & $8(0.5)^{S}$ & $8(0.5)^{S}$ & $2(0.125)^{S}$ & $4(0.25)^{S}$ & $8(0.5)^{S}$ & $16(1)^{\prime}$ \\
\hline & CM64 & 128 & $256(2)^{1}$ & $256(2)^{1}$ & $8(0.0625)^{\mathrm{S}}$ & $16(0.125)^{\mathrm{S}}$ & $128(1)^{\prime}$ & $128(1)^{\prime}$ & $256(2)^{1}$ & $256(2)^{1}$ \\
\hline & KP55 & 128 & $64(0.5)^{5}$ & $64(0.5)^{\mathrm{S}}$ & $64(0.5)^{S}$ & $64(0.5)^{\mathrm{S}}$ & $8(0.0625)^{S}$ & $16(0.125)^{\mathrm{S}}$ & $64(0.5)^{S}$ & $128(1)^{\prime}$ \\
\hline & KP63 & 8 & $32(4)^{1}$ & $32(4)^{1}$ & $4(0.25)^{S}$ & $4(0.25)^{S}$ & $8(1)^{\prime}$ & $8(1)^{\prime}$ & $8(1)^{\prime}$ & $8(1)^{\prime}$ \\
\hline & NAE16 & 32 & $8(0.25)^{S}$ & $16(0.5)^{S}$ & $8(0.25)^{S}$ & $8(0.25)^{S}$ & $4(0.125)^{S}$ & $4(0.125)^{S}$ & $8(0.25)^{\mathrm{S}}$ & $8(0.25)^{\mathrm{S}}$ \\
\hline & PA124 & 256 & $128(0.5)^{S}$ & $128(0.5)^{S}$ & $128(0.5)^{\mathrm{S}}$ & $128(0.5)^{S}$ & $128(0.5)^{S}$ & $128(0.5)^{S}$ & $256(1)^{1}$ & $256(1)^{1}$ \\
\hline
\end{tabular}

s: Synergy; I: Indifference; A: Antagonism; ( ): FIC values; -: MIC > $512 \mu \mathrm{g} / \mathrm{mL}$ or not determined FIC; ATB: Antibiotic; CIP: Ciprofloxacin, NOR: Norfloxacin, CHL: Chloramphenicol, STR: Streptomycin, TET: Tetracycline, KAN: Kanamycin, ERY: Erythromycin, AMP: Ampicillin and CEF Cefepime; The values in bold represent the cases of synergy between extract and antibiotic.

use in the control of MDR bacterial infections could therefore be of limited importance. None-the-less, the obtained results can be considered as interesting when considering the fact that the extracts are obtained directly from edible plant materials.

Efflux pumps are responsible for the reduction of intracellular concentration of antibacterial compounds [29]. To tackle problems related to this phenomenon, an intensive search of efflux pumps inhibitors (EPI) is welcome [30]. The EPI blocks the efflux pumps and leads to the increase of the intracellular concentration of active principle contents of the extracts $[29,31]$. The activity of B. oleacera var. butyris extract against the tested bacteria in the presence of $\mathrm{PA} \beta \mathrm{N}$, increased in $75 \%$ of the cases. This suggests that some compounds present in this extract could be substrates of efflux pumps $[31,32]$.

The extracts of B. oleacera var. butyris, B. oleracea var. Italica, Basilicum polystachyon and C. frutescens showed significant synergistic effects $(0.031<\mathrm{FIC}<0.5)$ with the majority of the tested antibiotics against the studied MDR strains. This suggests that the extracts might contain bioactive compounds that, combined with antibiotics, acted at different sites by various mechanisms [33,34]. These data indicate that a combination of these extracts with antibiotics could be envisaged to fight MDR bacteria.

\section{Conclusion}

These results provide promising baseline information for the potential use of Capsicum frutescens, Brassica oleacera var. italica, Basilicum polystachyon and Brassica oleacera var. butyris, independently or in combination with some commonly used antibiotics in the fight against MDR Gram-negative bacteria.

Competing interests

The authors declare that they have no competing interests.

\section{Authors' contributions}

FTK carried out the study; VK designed the experiments. FTK, AJS, AGF and VK wrote the manuscript; VK, JAKN and DED supervised the work; VK provided the bacterial strains; all authors read and approved the final manuscript.

\section{Acknowledgements}

Authors are thankful to the Cameroon National Herbarium (Yaounde) for plants identification.

Received: 18 April 2014 Accepted: 16 July 2014

Published: 21 July 2014

\section{References}

1. Hancock EW: Mechanisms of action of newer antibiotics for Gram-positive pathogens. Lancet Infect Dis 2005, 5:209-218.

2. Lomovskaya O, Bostian KA: Practical applications and feasibility of efflux pump inhibitors in the clinic-a vision for applied use. Biochem Pharmacol 2006, 71:910-918.

3. Noumedem JAK, Mihasan M, Kuiate JR, Stefan M, Cojocaru M, Dzoyem JP, Kuete $\mathrm{V}$ : In vitro antibacterial and antibiotic-potentiation activities of four 
edible plants against multidrug-resistant gram-negative species. BMC Complement Altern Med 2013, 13:190.

4. Patrick $H, N$ Nai $K, N g$ TB: A lectin with antifungal and mitogenic activities from red cluster pepper (Capsicum frutescens) seeds. Appl Microbiol Biotechnol 2007, 74:366-371.

5. Koffi-Nevry R, Kouassi CK, Nanga ZY, Koussémon M, Loukou GY: Antibacterial Activity of Two Bell Pepper Extracts: Capsicum annuum L and Capsicum frutescens. Int J Food Prop 2012, 15:961-971.

6. Ooi LS, Ng TB, Geng Y, Ooi VE: Lectins from bulbs of the Chinese daffodi Narcissus tazetta (family Amaryllidaceae). J Biochem Cell Biol 2000, 78:463-468.

7. YuL G, Milton JD, Fernig DG: Opposite effects on human colon cancer cell proliferation of two dietary Thomsen-Friedenreichantigen-binding lectins. J Cell Physiol 2001, 186:282-287.

8. Jeffery EH, Araya M: Physiological effects of broccoli consumption. Phytochem Rev 2009, 8:283-298.

9. Stergiopoulou T, De Lucca AJ, Meletiadis J, Sein T, Boue SM, Schaufele R, Roilides E, Ghannoum M, Walsh TJ: In vitro activity of CAY-1, a saponin from Capsicum frutescens, against Microsporum and Trichophyton species. Med Mycol 2008, 46:805-810.

10. Farzinebrahimi R, Mattaha R, Fadainasab M, Mokhtari S: In vitro plant regeneration, antioxidant and antibacterial studies on broccoli, Brassica oleracea var. italica. Diagn Micr Infec Dis 2012, 44:2117-2122.

11. Katayoon D, Akram T, Mahdi V: Investigation of Antipseudomanal Activity of Brassica Napus L. Singapore: Singapore: 2011.

12. Kyung KH, Fleming HP: Antimicrobial activity of sulfur compounds derived from cabbage. J Food Prot 1997, 60:67-71.

13. Charkraborty D, Mandal SM, Charkraborty J, Bhattacharyaa PK, Bandyopadhyay A, Mitra A, Gupta K: Antimicrobial Activity of Leaf Extract of Basilicum polystachyon (L) Moench. Ind J Exp Biol 2007, 45:744-748.

14. Monks TJ, Hanzlik RP, Cohen GM, Ross D, Graham DG: Quinone chemistry and toxicity. Toxicol Appl Pharmacol 1992, 112:2-16.

15. Lorenzi V, Muselli A, Bernadini AF, Berti L, Pagès JM: Geraniol restores Antibiotic activities against multidrug resistant isolates from Gram-negatives species. Antimicrob Agent Chemother 2009, 53:2209-2211.

16. Harborne JB: Phytochemical methods: A guide to modern techniques of plant analysis. 3rd edition. London, UK: Chapman \& Hall Pub; 1973.

17. Kuete V, Alibert-Franco S, Eyong KO, Ngameni B, Folefoc GN, Nguemeving JR, Tangmouo JG, Fotso GW, Komguem J, Ouahouo BMW, Bolla JM, Chevalier J, Ngadjui BT, Nkengfack AE, Pagès JM: Natural products against bacteria expressing multidrug resistant phenotype. Intl I Antimicrob Ag 2011, 37:156-161

18. Ghisalberti $D$, Masi M, Pagès JM, Chevalier J: Chloramphenicol and expression of multidrug efflux pump in Enterobacter aerogenes. Biochem Biophys Res Commun 2005, 328:1113-1118.

19. Fankam AG, Kuete V, Voukeng IK, Kuiate JR, Pagès JM: Antibacterial activities of selected Cameroonian spices and their synergistic effects with antibiotics against multidrug-resistant phenotypes. BMC Complement Altern Med 2011, 11:104.

20. Mativandlela SPN, Lall N, Meyer JJM: "Antibacterial, antifungal and antitubercular activity of (the roots of) Pelargonium reniforme (CURT) and Pelargonium sidoides (DC) (Geraniaceae) root extracts". S Afr J Bot 2006, 72(2):232-237.

21. Kuete V, Ngameni B, Simo CCF, Tankeu RK, Ngadjui BT, Meyer JJM, Lall N, Kuiate JR: Antimicrobial activity of the crude extracts and compounds from Ficus chlamydocarpa and Ficus cordata (Moraceae). J Ethnopharmacol 2008, 120:17-24.

22. Braga LC, Leite AAM, Xavier KGS, Takahashi JA, Bemquerer MP, Chartone-Souza E, Nascimento AMA: Synergic interaction between pomegranate extract and antibiotics against Staphylococcus aureus. Can J Microbiol 2005, 51(7):541-547.

23. Coutinho HD, Vasconcellos A, Freire-Pessoa HL, Gadelha CA, Gadelha TS, Almeida-Filho GG: Natural products from the termite Nasutiter mescorniger lower aminoglycoside minimum inhibitory concentrations. Pharmacognosy Mag 2010, 6:1-4

24. Perret S, Whitfield PJ, Sanderson L, Bartlett A: The plant molluscide Millettia thomingu (Leguminosae) as a tropical anti schistosamal agent. J Ethnopharmacol 1995, 47:49-54

25. Fernandez MA, Garcia MD, Saenz MT: Antimicrobial activity of the phenolic acids fractions of Scrophularia frutescens and Scrophularia sambucifolia. Pak J Bot 1996, 53:11-14.
26. Peres MTLP, Monache FD, Cruz AB, Pizzolatti MG, Ynes RA: Chemical composition and antimicrobial activity of croton Urucurana baillon (Euphorbiacecae). J Ethnopharmacol 1997, 56:223-226.

27. Brunetton J: Pharmacognosie: Phytochimie, Plantes medicinales. 3rd edition. Paris: Bourin, F; 1999:263-309.

28. Kuete V, Ngami B, Tangmouo JG, Bolla JM, Alibert-Franco S, Ngadjui BT, Pagès JM: Efflux Pumps are involved in the defense of Gram-Negative Bacterial against the natural products Isobavachalcone and Diospyrone. Antimicrob Agents Chemother 2010, 54(5):1749-1752.

29. Bohnert JA, Winfried VK: Selected arylpiperazines are capable of reversing multidrug resistance in Escherichia coli over expressing RND Efflux Pumps. Antimicrob Agents Chemother 2005, 49:849-852.

30. Hasdemir UO, Chevalier J, Nordmann P, Pagès JM: Detection and prevalence of active drug efflux mechanism in various multidrug efflux mechanisms in various multidrug resistant Klebsiella pneumoniae strains from Turkey. J Clin Microbiol 2004, 42:2701-2706.

31. Pagès $J M$, Amaral L: Mechanisms of drug efflux and strategies to combat them: challenging the efflux pump of Gram-negative bacteria. Biochem Biophys Acta 2009, 1794:826-833.

32. Marquez B: Bacterial efflux systems and efflux pumps inhibitors. Biochimie 2005, 87:1137-1147.

33. Lomovskaya O, Watkins W: Inhibition of efflux pumps as a novel approach to combat drug resistance in bacteria. $J$ Mol Microbiol Biotechnol 2001, 3(2):225-236.

34. Kuete V, Nana F, Ngameni B, Mbaveng AT, Keumedjio F, Ngadjui BT: Antimicrobial activity of the crude extract, fractions and compounds from stem bark of Ficus ovata (Moraceae). J Ethnopharmacol 2009, 124:556-561.

doi:10.1186/1472-6882-14-258

Cite this article as: Touani et al:: Antibiotic-potentiation activities of four Cameroonian dietary plants against multidrug-resistant Gram-negative bacteria expressing efflux pumps. BMC Complementary and Alternative Medicine 2014 14:258

\section{Submit your next manuscript to BioMed Central and take full advantage of:}

- Convenient online submission

- Thorough peer review

- No space constraints or color figure charges

- Immediate publication on acceptance

- Inclusion in PubMed, CAS, Scopus and Google Scholar

- Research which is freely available for redistribution 